\title{
História e culturas políticas: as concepções jurídicas evocadas pelos governos militares enquanto instrumento de obtenção de legitimidade
}

\author{
Márcia Pereira da SILVA ${ }^{\bullet}$
}

\begin{abstract}
Resumo: Este artigo se propõe a analisar o período dos governos militares brasileiros (1964-1985) sob a ótica da cultura da legalidade. Pretendemos demonstrar como a tomada do poder político em 1964, longe de se caracterizar apenas pelo emprego da força e do arbítrio, foi pautada por um esforço jurídico, produzido com base numa determinada teoria do direito constitucional, com ênfase no pensamento de Carl Schmitt e Hans Kelsen.
\end{abstract}

Palavras-chave: Cultura política; Forças Armadas; Brasil.

\section{Introdução}

As sociedades, já afirmou Daniel Aarão Reis Filho (2001:1), "têm sempre dificuldades em exercitar a memória sobre as suas ditaduras, sobretudo a partir do momento em que assumem códigos de valores opostos aos princípios do estado de exceção". Mas, como também insiste Hobsbawm (2000), os historiadores distinguem-se dos demais pesquisadores pelo ofício de fazer lembrar aquilo que a sociedade em geral, conscientemente ou não, teima em esquecer.

São infinitos os objetos sobre os quais os historiadores se debruçaram, mesmo quando o tema escolhido exigiu a retomada de eventos históricos que muitos prefeririam que não tivessem

\footnotetext{
- Professora Doutora Departamento de História - Faculdade de História, Direito e Serviço Social - UNESP - Campus de Franca - 14409-160 Franca - SP - Brasil. E-mail: marciapereirasilva@gmail.com 
MÁRCIA PEREIRA DA SILVA

acontecido. É esse o caso dos governos militares ${ }^{1}$.

É relativamente vasta a literatura já produzida acerca dos governos militares, mas escassa as obras que procuraram tratar do funcionamento da lógica do governo, sobretudo quando a ênfase recai em questões pertinentes à legalidade. A simples referência ao termo legalidade, inserido no contexto dos governos em questão, parece causar certo constrangimento, como se pretendesse o pesquisador que ao tema se dedique comungar com um tipo de poder político pautado na força e na violência.

Nesse sentido, o objetivo desse texto é avaliar as concepções jurídicas difundidas e/ou utilizadas pelos governos militares. Para tanto, recorremos aos preâmbulos dos Atos Institucionais e aos discursos dos generais presidentes.

\section{A cultura da legalidade e os governos brasileiros de 1964 a 1986}

Em 1964, os brasileiros passaram a conviver com um regime político de estrutura e ideologia autoritárias. Estrutura autoritária porque buscou concentrar o poder político nas mãos de um grupo burocraticamente organizado, reduzindo a importância e a participação das instâncias de representação popular; ideologia autoritária porque privilegiava a hierarquia enquanto organização da comunidade política, com o fim de preservar uma determinada ordem social considerada como essencial à manutenção da segurança nacional (BOBBIO, MATTEUCCI, PASQUINO, 1999).

Governos em regimes autoritários, como quaisquer outros, necessitam de legitimidade, que, como atributo do Estado, "consiste na presença,em uma parcela significativa da população, de um grau de consenso capaz de assegurar a obediência",com o uso esporádico da força, mas sem a necessidade do uso da violência (BOBBIO, MATTEUCCI, PASQUINO, 1999:675) ${ }^{2}$. 
HISTÓRIA E CULTURAS POLÍTICAS: AS CONCEPÇÕES JURÍDICAS ...

Como não conseguiram eliminar a diversidade da tessitura social e merecerem o consenso almejado, os governos autoritários brasileiros do período em questão conviveram com uma constante crise de legitimidade. Para combatê-la, lançaram mão de inúmeros artifícios: força, repressão, medidas econômicas que beneficiavam a classe média, propaganda e edição de inúmeras leis que lhes propiciassem o discurso de que tomavam medidas com base na legalidade e não no arbítrio.

Acreditamos que a ênfase dos governos militares na difusão de que as medidas políticas que tomavam estavam de conformidade com a legislação nacional (mesmo que para tanto tenham, eles próprios, editado inúmeras leis) foi uma importante estratégia de obtenção de legitimidade, evidenciando a cultura da legalidade desenvolvida no decorrer da história do Brasil como parte integrante da cultura política nacional.

Compreendemos cultura política de modo mais amplo do que a clássica definição de Gabriel Almond e Sidney Verba (1989:12). Para os mesmos, o termo "refere-se às orientações especificamente políticas, às atitudes com respeito ao sistema político, suas diversas partes e o papel dos cidadãos na vida pública".

$\mathrm{Na}$ última década o conceito ganhou elasticidade e profundidade, passando a abarcar comportamentos, crenças, símbolos, práticas e representações políticas predominantes em determinados grupos sociais num dado momento histórico. Cada sociedade desenvolve uma série de culturas políticas que se interiorizam e acabam sendo a ossatura do comportamento político de seus membros.

$\mathrm{Na}$ década de 1960, a cultura da legalidade já integrava a cultura política brasileira.

Desde que o Brasil se tornou uma nação independente, impôs-se a necessidade de uma lei máxima que fornecesse estabilidade à nova ordem política, regulamentasse os direitos e deveres de governados e governantes.

A primeira Assembléia Constituinte brasileira foi convocada em 1822, antes da independência. Em setembro de 1823, o primeiro projeto de Constituição do Brasil foi vetado pelo 
Imperador D. Pedro I, a chamada Constituição da Mandioca. Um ano depois, outro texto foi outorgado como a Constituição de 1824. Esta ampliou o poder do Imperador, em relação ao primeiro projeto, ao criar o Poder Moderador.

Durante o primeiro Reinado, no tocante ao Direito Constitucional, foram editados uma Acta (1822), duas Proclamações (1823), um Manifesto (1823) e uma Lei (1828). No período regencial foram três Leis (1832/34 e 40); no segundo Reinado, a Lei de 1841.

Depois da proclamação da República, o Brasil conheceu várias Constituições e, para cada uma delas, vários adendos (ver Quadro 1).

QUADRO 1 - Constituições e Adendos do Brasil republicano: de 1889 até o Golpe de 1964

\begin{tabular}{|c|c|c|c|}
\hline & Adendo & quantidade & data \\
\hline \multirow[t]{9}{*}{ Constituição de 1891} & Proclamação & 01 & 1889* \\
\hline & \multirow[t]{5}{*}{ Decreto } & 02 & 1889 \\
\hline & & 01 & 1890 \\
\hline & & 04 & 1891 \\
\hline & & 01 & 1892 \\
\hline & & 01 & 1930 \\
\hline & Parecer & 02 & 1891 \\
\hline & Lei & 01 & 1892 \\
\hline & Emenda & 01 & 1926 \\
\hline Constituição de 1934 & Decreto Legislativo & 01 & 1935 \\
\hline \multirow[t]{8}{*}{ Constituição de 1937} & \multirow[t]{3}{*}{ Decreto-Lei } & 01 & 1939 \\
\hline & & 01 & 1943 \\
\hline & & 01 & 1945 \\
\hline & \multirow[t]{5}{*}{ Lei } & 02 & 1938 \\
\hline & & 02 & 1940 \\
\hline & & 04 & 1942 \\
\hline & & 11 & 1945 \\
\hline & & 02 & 1946 \\
\hline \multirow[t]{4}{*}{ Constituição de 1946} & \multirow{4}{*}{$\begin{array}{c}\text { Emenda } \\
\text { Constitucional }\end{array}$} & 01 & 1950 \\
\hline & & 01 & 1956 \\
\hline & & 03 & 1961 \\
\hline & & 01 & 1963 \\
\hline
\end{tabular}

* A legislação anterior à edição da Constituição refere-se ao governo provisório e aos primeiros meses da República. Foi editada com o 
HISTÓRIA E CULTURAS POLÍTICAS: AS CONCEPÇÕES JURÍDICAS ...

objetivo de permitir a organização do regime Republicano enquanto se preparava o texto constitucional.

A quantidade de legislação editada no Brasil até 1964 é considerável. Com o golpe não foi diferente, tampouco com a abertura. Durante os governos militares foram produzidas 01 Constituição, 17 Atos Institucionais, 105 Atos Complementares e 42 Emendas Constitucionais, incluindo a Emenda n.01/69 que de tão extensa ficou conhecida como a "Constituição de 1969".

Apenas a título de comparação, convém salientar que a última Constituição brasileira, editada em 1988, já ganhou 56 Emendas. Já a norte-americana, datada de 1787, foi emendada apenas 27 vezes.

A Constituição brasileira muda tanto porque os textos são minuciosos e detalhistas (prolixos mesmo), com análises e proposições que extrapolam, em muito, o estabelecimento das configurações gerais da nação e a ossatura do regime republicano. Como dispõe sobre quase tudo (inclusive sobre elementos que poderiam estar em legislações complementares), muda muito em virtude da multiplicidade das relações sociais sempre em movimento. Enquanto as Constituições do Brasil tem em média 200 artigos, a norte-americana tem $09^{3}$.

Até o momento, exemplificamos a enorme quantidade de leis no Brasil apenas no tocante ao Direito Constitucional. O leitor pode imaginar como esse número aumentaria se nos dedicássemos ao conjunto das normas publicadas no país para reger a vida dos cidadãos.

Desde 05 de outubro de 1988 (data da promulgação da atual Constituição Federal), até 05 de outubro de 2008 (seu 20 aniversário), foram editadas no Brasil 3.776.364 normas (...). Isso representa, em média, 517 normas editadas todos os dias ou 774 normas editadas por dia útil (AMARAL, 2008:1).

Essa quantidade de leis sucessivamente editadas exemplifica, a nosso ver, a cultura da legalidade existente em nosso país. No Brasil, a cultura da legalidade é traduzida pela necessidade do grupo político no governo alegar sempre pautar- 
se num conjunto de normatizações que regem a sociedade. Nós brasileiros estamos, em muitos aspectos, acostumados à tutela do Estado, traduzida em leis públicas referentes aos direitos sociais. Nosso hábito cultural não abarca, infelizmente, a prática de recorrer à justiça para resolver atritos entre os membros da sociedade, já que nesses casos costumamos apelar para os favores, numa prática político-pessoal que remonta aos tempos do coronelismo. Entre nós, a cultura política da legalidade está restrita à dominação política do Estado. Nesse sentido, não seria possível ao grupo civil-militar que tomou o comando do Estado brasileiro em 1964 fazê-lo, desconsiderando as leis que regem o país e ainda assim alcançar alguma legitimidade.

Sabia o comando do movimento civil-militar de 1964 que a tradição nacional já havia incorporado o elemento da legalidade. No Brasil, não era possível simplesmente desprezar as leis: era preciso construir o simulacro, disfarçar o arbítrio e fazer crer que as ações dos governos militares tinham bases legais ${ }^{4}$.

$\mathrm{Na}$ opinião de Renato Lemos (2004:415), a preocupação com a formalidade legal/jurídica significou mais do que "mero preconceito juridicista, traduzindo uma dificuldade de atuar [o governo instituído em 1964] à margem de certo paradigma da cultura política". Nesse sentido, o autor alerta para o fato de que

no mundo de pós-guerra, o "mercado mundial de idéias" estabeleceu a legitimidade democrático-representativa como pré-requisito para a aceitação da dominação política, o que impôs aos regimes não-democráticos surgidos a partir de então um quadro de "esquizofrenia ideológica": praticar o autoritarismo no presente prometendo a democracia no futuro.

Quanto à preocupação com a legalidade, Luiz Vianna Filho (1975: 56) lembrou a irritação de Costa e Silva pela demora na definição do primeiro Ato Institucional. Insistia o general: "que lhe dessem algum documento, 'qualquer coisa' (...) que lhe permitisse iniciar as punições" ${ }^{5}$. 
HISTÓRIA E CULTURAS POLÍTICAS: AS CONCEPÇÕES JURÍDICAS ...

Com efeito, Irene Cardoso (1997:473) aponta a combinação legalidade/legitimidade como "sustentáculo" do Estado autoritário brasileiro:

(...) a ênfase na legalidade e na legitimidade (sustentáculos do regime ditatorial) teve um significado preciso: o da criação de uma aparência de normalidade para a vida social e política que impedisse o reconhecimento do regime a partir da perspectiva da excepcionalidade e do arbítrio.

Justamente em virtude do que estamos chamando de cultura da legalidade, não foram parcos os esforços dos governos militares em editar leis e divulgar uma determinada concepção jurídica que favorecessem a manutenção do Estado autoritário. Insistimos: a edição da legislação nacional estava (e ainda está) pautada em determinados princípios formadores do Direito Constitucional. Não bastava aos governos militares, em nome da legitimidade, apenas editar as leis, mas deveriam fazê-lo de conformidade com justificativas teóricas difundidas pela ciência do Direito, sob pena de não serem reconhecidos como legítimos.

\section{O Direito Constitucional enquanto instrumento de obtenção de legitimidade dos governos militares brasileiros}

O Direito Constitucional é, enquanto subárea do conhecimento, apontado como um ramo do Direito Público, obviamente por aqueles que admitem a dicotomia entre o Direito Público e o Privado. No entanto, convém ressaltar a dificuldade em se demarcar uma linha divisória entre o público e o privado, entre o interesse da pessoa enquanto indivíduo e como membro da coletividade. A divisão entre Direito Público e Privado tem sido questionada pela ciência jurídica, mas continua em uso por motivações didáticas. Portanto, o Direito Constitucional permanece compreendido como o principal ramo do Direito Público que trata da organização e atividade do Estado, 
considerado de forma mais ou menos ampla, segundo se tome a Constituição em sentido apenas jurídico ou também político.

De qualquer modo, a edição das leis supremas que regem uma dada sociedade, no sentido das normas estruturadoras e fundamentais do Estado, diz respeito ao Direito Constitucional.

Mas quem edita as leis? Quando a lei é legítima? As respostas dessas questões devem ser procuradas nas teorias sobre o poder constituinte.

As origens das concepções de poder constituinte remontam à Revolução Francesa. Sieyès publicou, em 1789, o conhecido texto Qu'est-le que le Tiers État? Nele, o autor defende que o Terceiro Estado, considerado maioria numérica absoluta na França e que não gozava de representação correspondente, deveria alcançar certos direitos políticos por meio de uma lei oriunda do poder constituinte. Sieyès parte da hipótese de que os homens, no estado de natureza, eram livres e tinham direitos iguais. Nesse estado originário a sociedade política teria nascido de um pacto social, em nome da institucionalização de um poder que garantisse a sobrevivência do ser social e de seus direitos naturais ${ }^{6}$. Esse poder acordado seria, ainda segundo Sieyès, organizado e limitado por uma série de normas estabelecidas por representantes extraordinários do povo - legítimo autor da Constituição (SIEYÈS, 1988).

Segundo Manuel Ferreira Filho (2003:43), a apropriação dos conceitos de Sieyès pelos escritos jurídicos posteriores significou a "transmutação de uma doutrina habilmente exposta para fins políticos imediatos numa pretensa teoria cientifica do poder constituinte".

Quando os autores que escreveram sobre o poder constituinte advertiram para a necessidade de o grupo que elabora a Constituição representar a vontade geral da nação, na verdade estavam defendendo o princípio de que esse grupo deve ser identificado enquanto tal.

No geral, os teóricos do Direito Constitucional concordariam que o poder constituinte é dividido entre "originário" e "instituído". O primeiro é exercido pelo povo, não está subordinado a nenhuma normatização anterior e representa 
HISTÓRIA E CULTURAS POLÍTICAS: AS CONCEPÇÕES JURÍDICAS ...

a vontade geral da nação. Já o poder constituinte instituído é subordinado ao originário, geralmente exercido por uma Assembléia Nacional Constituinte e obediente às normas estabelecidas pela comunidade política.

Apesar do Direito Constitucional ser uma área do conhecimento com concepções gerais partilhadas pela maioria dos pesquisadores e juristas, a história registra autores que discordaram de interpretações mais comuns ou se dedicaram a construir teorias específicas acerca desse ou daquele ponto.

Quando a lei máxima de uma nação pode ser modificada? É possível alterar o governo de um país fora dos processos previstos pela Constituição em vigor e ainda assim falar de legalidade? Encontramos respostas diferentes para essas questões, dependendo do autor ao qual recorremos para justificá-las.

O Direito Constitucional e suas inúmeras interpretações ofereceram bases teóricas para a tomada do poder do Estado em 1964. Como esperamos deixar claro neste artigo, os preâmbulos dos Atos Institucionais e os discursos dos generais presidentes autorizam a afirmação de que os governos militares (e/ou os autores da legislação no período) conheciam as diferentes concepções do Direito Constitucional, a ponto de alegar que "o governo Revolucionário de 1964 era portador do poder constituinte originário", afirmação do preâmbulo do AI-1.

Segundo Rouquié (1984), governos autoritários como o brasileiro desenvolvem duas estratégias para legitimidade. Primeiro, fazem o discurso, intencional ou não, de que possuem caráter transitório porque são necessários para conter um mal atual (no caso, o comunismo) e, em seguida, procuram se institucionalizar por meio de legislações futuras que lhes concedam base para ações várias, sempre aproveitando o máximo da estrutura administrativa, política e burocrática já existente. Serão, portanto, governos sempre percebidos em sua excepcionalidade, apesar do apelo para a legalidade, tidos como urgentes no momento em que emergem, em nome da redenção democrática do futuro. 
MÁRCIA PEREIRA DA SILVA

No Brasil, cada edição de um Ato Institucional foi acompanhada de um preâmbulo que explicava o motivo daquela lei e as razões do governo para fazê-la, evocando princípios jurídicos específicos e especialmente selecionados para servir aos propósitos do autoritarismo. Desses preâmbulos, chamaramnos a atenção as referências ao pensamento de Carl Schmitt e Hans Kelsen, mais do primeiro do que do segundo.

Schmitt e Kelsen tinham concepções diferentes sobre o status, o significado e o objetivo da legislação de um dado país. Ambos protagonizaram, inclusive, um interessante debate sobre poder político e Constituição na primeira metade do século XX.

Em 1929, foi publicado o conhecido ensaio de Carl Schmitt, Der Hüter der Verfassung (ou O guardião da Constituição), no periódico Archiv dês öffentlichen Rechts. Nele, Schmitt defende a submissão do Direito à política, compreendendo a última não como a relação de poder entre diferentes grupos e interesses sociais divergentes, mas como o conjunto da ação do Estado soberano que avalia tudo e todos como amigos ou inimigos. Para o autor, o chefe do Estado está acima das leis constitucionais e deve proteger a nação, mesmo que tenha que suspender a própria Constituição. Aqui é importante diferenciar leis constitucionais (conjunto de normatizações tornadas válidas na Constituição) de Constituição (que se valida na decisão da unidade política). Carl Schmitt dá muita importância a tal diferenciação, subordinando sempre a Constituição à política. Pelo mesmo motivo, o autor critica Kelsen, argumentando que o segundo equipara Constituição e leis constitucionais, num quadro teórico comumente denominado de teoria pura do Direito.

Em resposta ao texto de Schmitt, Hans Kelsen escreveu Wer soll der Hüter der Verfassung sein? (ou Quem deve ser o guardião da Constituição?), ensaio publicado no periódico Die Justiz. Nesse trabalho, Kelsen critica o que julga ser a excessiva influência da política, dos interesses políticos, do poder Executivo e da moral (e/ou juízo de valor sempre relativo e diferente para cada época histórica) no processo constitucional. Para Kelsen, o corpo de leis deve ser examinado eliminando o 
HISTÓRIA E CULTURAS POLÍTICAS: AS CONCEPÇÕES JURÍDICAS ...

máximo possível de influências externas ao Direito Constitucional.

Em resumo, o debate entre Schmitt (jurista alemão que aderiu ao nazismo) e Kelsen (jurista judeu) sobre quem deve "guardar" a Constituição pode ser assim expresso: para o primeiro, o detentor da soberania está acima da Constituição em razão da manutenção da unidade de um Estado totalizante; já para o segundo, a política não deve subjugar o Direito e o poder Judiciário não é menos importante que o Executivo.

Levando em consideração o contexto histórico em que o debate ocorreu - disseminação do fascismo pela Europa podemos afirmar que as proposições de Kelsen estavam bem mais próximas da democracia do que as de Schmitt.

Apesar de diferentes, tanto Schmitt como Kelsen defenderam idéias que foram evocadas no contexto dos governos militares pelo grupo dominante, por motivos e em ocasiões diferentes.

\section{As concepções jurídicas de Carl Schmitt e os governos militares no Brasil}

Carl Schimitt (1888-1985) foi alemão, jurista e professor. Manteve relações com o nazismo e ascendeu profissionalmente sob a égide do totalitarismo. Seu pensamento foi utilizado para justificar vários aspectos da ideologia alemã do tempo de Hitler e várias ações do Estado nazista.

Em virtude de seu envolvimento com o nazismo, muito da produção de Carl Schimitt ainda é vista com restrição ${ }^{7}$.

No ano de 1921, Schmitt publicou o ensaio intitulado "Die Diktatur". Nessa e em outras publicações, apesar de as mesmas estarem voltadas para a República de Weimar, encontramos uma lógica e bem elaborada teoria de justificação de governos autoritários.

Dois elementos da teoria de Schimitt foram extremamente propícios ao tipo de poder do Estado defendido pelos governos 
MÁRCIA PEREIRA DA SILVA

militares no Brasil: o estado de exceção e a concepção de soberania.

O estado de exceção, no aporte teórico schmittiano (1931; 1968; 1992), é caracterizado pelo fato de "o soberano estar, ao mesmo tempo, dentro e fora do ordenamento jurídico", o que lhe dá o direito de, em momentos excepcionais, alterar a lei. Nesse sentido, o jurista alemão desenvolveu argumentos acerca da necessidade de uma ditadura soberana, bem como descreveu de que forma ela iria caracterizar-se no momento em que se tornasse necessária. Segundo Schmitt, em momentos de crise, o Estado deveria ficar sob o comando de um grupo capaz de decidir sobre as questões políticas e resolver aquela situação adversa. Tal grupo comporia um governo absoluto com poder de suspender a vigência constitucional, alterar a Carta Magna e até mesmo propor outro Estado de direito, em virtude de sua condição revolucionária.

Falando mais claramente: como "não existe nenhuma norma que seja aplicável ao caos (...), primeiro se deve estabelecer a ordem: só então faz sentido o ordenamento jurídico (...)" (AGAMBEN, 2002:23,24). Assim, o pensamento schmittiano era extremamente oportuno para o discurso autoritário de 1964, pois justificava a intervenção política e jurídica de retorno "à ordem e aos bons costumes".

Na avaliação de Giorgio Agamben (2003:54),

o aporte físico da teoria schimitiana é exatamente o de tornar possível a articulação entre o estado de exceção e a ordem jurídica. Trata-se de uma articulação paradoxal, pois o que deve ser inscrito no direito é algo essencialmente exterior a ele, isto é, nada menos que a suspensão da própria ordem jurídica.

A proximidade entre a teoria proposta por Schmitt e a concepção jurídica oficial do período dos governos militares brasileiros já foi sugerida por Nilson Borges. Ao procurar pelas semelhanças entre o jurista e os governos militares, Nilson Borges (2003:27) afirmou que para ambos o governo se define 
HISTÓRIA E CULTURAS POLÍTICAS: AS CONCEPÇÕES JURÍDICAS ...

como o órgão ou a pessoa que decreta um estado de crise, suspendendo os direitos e instaurando as restrições à ação política. A ditadura soberana se fundamenta na capacidade de a revolução se legitimar por ela mesma e de substituir toda a jurisdição existente (grifos do autor).

Ora, foi exatamente a necessidade de um estado de exceção o argumento central dos governos militares para a tomada do poder em 1964 e a instalação de um governo revolucionário. A historiografia já demonstrou à exaustão a difusão do imaginário contra o comunismo e o perigo vermelho, o esgotamento da política populista e/ou o temor do movimento trabalhista, enfim, a realidade da participação política popular que exigia maior representatividade nas décadas de 1950 e 60. Diante da emergência de setores mais populares na política nacional, grupos mais tradicionais recorreram ao autoritarismo para a manutenção de antigos privilégios de dominação. $O$ estado de exceção foi então justificado como necessário na manutenção da ordem e dos bons costumes.

$\mathrm{Na}$ visão de Giorgio Agamben, a definição de estado de exceção de Carl Schmitt permite inclusive justificar a repressão aos considerados subversivos. Segundo Agamben (2003:13), a exceção é o elemento constitutivo do autoritarismo moderno, uma vez que abarca "a instauração de uma guerra civil legal que permite a eliminação física não só dos adversários políticos, mas também de categorias inteiras de cidadãos que, por qualquer razão, pareçam não integráveis ao sistema político".

Se considerarmos o estado de exceção e a soberania schmittianos, é pertinente afirmarmos que nada houve de ilegal na tomada do poder do Estado em 1964, uma vez que poderíamos argumentar que as Forças Armadas avaliaram o perigo à segurança nacional enfrentado pelo país naquele momento histórico e instauraram a ditadura soberana.

Para Carl Schmitt (2007), o guardião da Constituição, com poder para alterá-la ou não, é sempre o chefe do Estado. Mas o autor está se referindo à Alemanha nazista e, portanto, identifica 
a soberania do país e o dever de manter a ordem interna com o fürer. No caso do Brasil, as coisas eram bem diferentes.

O governo estava na mão de João Goulart, que tinha grande oposição interna, tanto da direita (que o acusava de ceder demais aos anseios populares), como da esquerda (que não via concretizadas as prometidas reformas).

No início do ano de 1964, Jango foi acusado de permitir o crescimento da ameaça comunista, o que era considerado ameaça à segurança do país. Portanto, o Chefe de Estado no Brasil estava longe de ser compreendido enquanto o portador da soberania nacional. Aliás, o dever de manter a ordem e defender a soberania já tinha sido atribuído às Forças Armadas pelas constituições brasileiras. Desde a primeira Constituição republicana, as Forças Armadas ganharam autonomia e viram ampliadas suas funções, até que o texto constitucional de 1934 introduziu o termo "ordem" como função dos militares: "As forças armadas são instituições nacionais permanentes, e, dentro da lei, essencialmente obedientes aos seus superiores hierárquicos. Destinam-se a defender a Pátria e a garantir os poderes constitucionais, a ordem e a lei" (grifo nosso).

A questão é que o termo ordem sugere uma função que transborda a lei; trata-se de um conceito informado mais pelos interesses dos poderes constituídos do que por concepções jurídicas. Ao tratar do assunto, Roberto de Aguiar (1986:21) escreveu que

a ordem se torna acima da lei e, em seu nome e até mesmo para a manutenção da lei, a estrutura jurídica é negada, levando as Forças Armadas a tutelar ordens políticas ou a derrubá-las, com a justificativa de uma manutenção da ordem, que nada mais é do que um termo retórico que traduz o confronto entre a ordem jurídico-política da lei e a nova ordem emergente de novos rearranjos e compromissos entre os grupos hegemônicos em uma dada sociedade.

Complementa o autor que, ao atribuir às Forças Armadas a função de guardiãs da ordem, o legislador deixou "aberta a porta 
HISTÓRIA E CULTURAS POLÍTICAS: AS CONCEPÇÕES JURÍDICAS ...

legal para uma crescente intervenção militar na vida política brasileira" (AGUIAR, 1986:21). Assim, o dever de guardar a Constituição ficou transferido para as Forças Armadas.

De posse do poder advindo da crença na necessidade de proteger a soberania nacional da influência socialista, seria possível e até mesmo preciso, segundo Schmitt, que se adequasse a Constituição aos novos tempos, fora dos processos previstos pela Carta Magna anterior.

Em 1964 estava em vigor a Constituição de 1946 que regulamentava as exigências para sua própria modificação.

Art 217 - A Constituição poderá ser emendada.

$\S 1^{\circ}$ - Considerar-se-á proposta a emenda, se for apresentada pela quarta parte, no mínimo, dos membros da Câmara dos Deputados ou do Senado Federal, ou por mais da metade das Assembléias Legislativas dos Estados no decurso de dois anos, manifestando-se cada uma delas pela maioria dos seus membros.

$\S 2^{\circ}$ - Dar-se-á por aceita a emenda que for aprovada em suas discussões pela maioria absoluta da Câmara dos Deputados e do Senado Federal, em duas sessões legislativas ordinárias e consecutivas.

$\S 3^{\circ}$ - Se a emenda obtiver numa das Câmaras, em duas discussões, o voto de dois terços dos seus membros, será logo submetida à outra; e, sendo nessa aprovada pelo mesmo trâmite e por igual maioria, dar-se-á por aceita.

$\S 4^{\circ}$ - A emenda será promulgada pelas Mesas da Câmara dos Deputados e do Senado Federal. Publicada com a assinatura dos membros das duas Mesas, será anexada, com o respectivo número de ordem, ao texto da Constituição.

$\S 5^{\circ}$ - Não se reformará a Constituição na vigência do estado de sítio.

$\S 6^{\circ}$ - Não serão admitidos como objeto de deliberação projetos tendentes a abolir a Federação ou a República.

Como não obedeceu ao Artigo 217, o AI-1 (primeiro Ato Institucional a tratar do novo governo) foi editado por meio de "processos não previstos pela Constituição" e, por isso mesmo, é apontado por muitos como evidência do golpe de Estado 
imposto à maioria dos brasileiros. No entanto, se recorrermos ao pensamento de Carl Schmitt, podemos argumentar que em meio a ameaça à ordem nacional instalou-se a ditadura soberana, regime autoritário que pode ser necessário para a sobrevivência de um país.

Os governos militares difundiram, por meio dos preâmbulos dos Atos Institucionais e nos discursos oficiais de representantes do Executivo, a defesa teórica que Schmitt fazia de regimes políticos pautados no autoritarismo, iniciados por golpes de Estado.

\section{As concepções jurídicas de Hans Kelsen e os governos militares no Brasil}

Principal expoente daquilo que conhecemos por Escola Positivista do Direito, Hans Kelsen (1881-1973) tornou-se um dos juristas mais influentes do século XX.

De origem judaica, Kelsen sofreu a perseguição nazista e fugiu para os EUA, local em que se tornou conhecido docente e escritor. No livro intitulado Teoria Pura do Direito, Kelsen expôs o cerne de suas concepções jurídicas. Para ele, o Direito, enquanto ciência, deve se constituir em um conjunto de pensamento que exclua influências e reflexões de elementos que não sejam as leis propriamente ditas. Explica-se: o autor considera que as questões morais e os valores são objetos estranhos ao Direito, advogando que referências sociológicas e axiológicas são matérias de estudo de outras ciências. Assim, a justiça, por exemplo, deixa de ser objeto do Direito. Argumenta Kelsen que o bem, o bom, o mal e o mau são valores históricos, variáveis em concepções e conteúdos através dos lugares e do tempo e que o Direito deve se tornar um campo de conhecimento universalmente válido e aplicável.

Ainda sobre Kelsen, é importante enfatizar que o autor não se dedicou apenas a obras sobre Direito, também publicou reflexões acerca da política e da democracia. Em virtude de sua 
HISTÓRIA E CULTURAS POLÍTICAS: AS CONCEPÇÕES JURÍDICAS ...

vasta obra, normalmente se separa o pesquisador em duas vertentes: o Kelsen jurista e o político. Neste trabalho, abordamos apenas o primeiro, tendo em vista que consideramos que nas publicações dos AIs os autores mencionaram as reflexões jurídicas de Kelsen e não suas abordagens sobre a democracia.

Como Carl Schmitt, Hans Kelsen também acredita que a lei máxima de uma nação pode ser alterada por processos não previstos na Constituição, mas não porque defenda a total supremacia da política sobre o Direito. Para Kelsen, uma geração tem sempre o poder de rever suas orientações, se considerarmos a chamada "efetividade da legislação" e o fato da mesma ser modificada "por legítimos representantes do povo".

A efetividade de uma dada lei ou Constituição e a do próprio poder constituinte diz respeito ao fato da lei ser globalmente eficaz e do grupo que a elabora ser reconhecido como legítimo representante da nação. A questão da efetividade está acima da existência ou não de uma Assembléia Constituinte, mesmo que a idéia da Assembléia já faça parte da tradição jurídica prevalecente na comunidade política (como é o caso do Brasil na década de 1960). Assim, a condição primeira da existência da norma é a sua efetividade, ou seja, "o fato de esta norma ser aplicada pelos órgãos jurídicos, especialmente pelos tribunais (...)" como também "o fato de esta norma ser respeitada pelos indivíduos subordinados à ordem jurídica", sob pena de a mesma deixar de existir [a lei] por permanecer "duradouramente ineficaz" (KELSEN, 1979:35).

A inexistência de uma regra fixa e rígida para alterações no conjunto da legislação de um dado país foi exposta como necessidade pelo próprio Sieyès (1988:69) no período da Revolução Francesa, num texto evocado sempre como o início da sociedade política democrática de direito: "de quelque manière que la nation veuille, il suffit qu'elle veuille; toutes lês formes sont bonnes et sa volonté est toujours la loi suprême".

Apesar da variedade das formas que o poder constituinte possa ganhar, um elemento parece ser consenso: o titular do poder constituinte é, necessariamente, o povo. Atribuir a 
titularidade do poder constituinte ao povo significa dizer que as leis precisam ser editadas em nome da maioria dos membros da nação e/ou por eles aprovada. Por ocasião do Ato Institucional $\mathrm{n}^{\circ}$ 1, as Forças Armadas proclamaram-se legítimos representantes do povo (e/ou portadores do poder constituinte); editaram o AI-1 e empreenderam grande esforço para convencer diversos setores sociais de que o mesmo lhes beneficiava. Se conseguissem aprovação de considerável parcela da sociedade para a legislação que passaram a editar, os governos militares alcançariam a efetividade constitucional.

O grupo que se torna portador do poder constituinte pode chegar a sê-lo de várias maneiras. Conforme afirma Hans Kelsen (1979:35),

do ponto de vista jurídico, é indiferente que a modificação da situação jurídica seja produzida através de um emprego da força dirigida contra o governo legítimo ou pelos próprios membros deste governo, através de um movimento de massas populares ou de um pequeno grupo de indivíduos.

Para o autor, o importante é salientar que também é legítimo o "fato de a Constituição vigente ser modificada ou completamente substituída por uma nova Constituição, através de processos não previstos pela Constituição" (KELSEN, 1979:35), desde que se observe a efetividade da nova normatização. Tal concepção autoriza, no limite, a reformulação da constituição nos próprios artigos que dizem respeito a normas para futuras emendas e alterações.

O governo militar, para a edição do AI-1, alegou esse princípio da teoria do poder constituinte, ou seja, a máxima da não sujeição de gerações futuras às leis passadas. $O$ discurso de apresentação do primeiro Ato Institucional confirma que os militares mais diretamente afinados com a perspectiva da efetiva dominação autoritária do Estado tinham consciência das diferentes concepções do poder constituinte e da existência de teorias do Estado que justificavam a tomada do poder por processos não previstos constitucionalmente. Os próprios 
HISTÓRIA E CULTURAS POLÍTICAS: AS CONCEPÇÕES JURÍDICAS ...

termos empregados na apresentação do AI-1 revelam que o texto foi escrito por alguém acostumado com a leitura jurídica:

(...) a revolução vitoriosa, como Poder Constituinte, se legitima por si mesma. Ela destituiu o governo anterior e tem a capacidade de constituir o novo governo. Nela se contém a força normativa, inerente ao Poder Constituinte. Ela edita as normas jurídicas sem que nisso seja limitada pela normatividade anterior à sua vitória. ${ }^{8}$

Em maio de 1964, durante vigência da junta revolucionária, foram editadas leis que permitiram futuras normatizações oriundas de setores privilegiados do governo, no sentido de construir um aparato legal para dar sustentação à situação de exceção. Futuras adequações jurídicas propostas pelo Executivo foram sendo, sucessivamente, previstas dentro do próprio texto constitucional alterado. Explica-se: os tradicionais caminhos para a edição de novas leis - aprovação e proposição pelos políticos eleitos para mandatos legislativos - foram retirados do texto constitucional que, pouco a pouco, foi concentrando nas mãos do Presidente e de seus assessores mais diretos o poder para legislar.

O AI-1, assinado pelos chefes das três armas - General Arthur da Costa e Silva, Brigadeiro Francisco de Assis Corrêa de Melo e Vice-Almirante Augusto Hamann Grunewald redimensionou os poderes do Presidente da República com a alegação, publicada logo no início da Apresentação do Ato, de que era preciso possibilitar-lhe

cumprir a missão de restaurar no Brasil a ordem econômica e financeira e tomar as urgentes medidas destinadas a drenar o bolsão comunista, cuja purulência já havia infiltrado não só na cúpula do governo, como nas suas dependências administrativas.

Depois do AI-1, Ato que instala o governo Revolucionário, uma norma foi permitindo a outra e assim por diante. A grande quantidade de normatizações editadas nos primeiros 
MÁRCIA PEREIRA DA SILVA

anos dos governos militares impôs a publicação de outra Constituição, divulgada no ano de 1967. O preâmbulo dos primeiros AIs traziam argumentos teóricos do Direito Constitucional habilmente enunciados para justificar o governo autoritário. Com o tempo, a notável quantidade de leis editadas fez com que o processo da constitucionalidade no Brasil fosse percebido como uma espécie de "histeria legal".

Então os preâmbulos da legislação passaram a alegar a legalidade do ato de promulgá-las, sempre se reportando a uma lei anterior. Era como se as razões políticas tivessem sido relegadas a um segundo plano e o mais importante fosse o ato de legislar, pura e simplesmente. Nessas ocasióes, o legislador lembrava Hans Kelsen, com o argumento de que a norma é desprovida de razões externas ao Direito. Afinal, o que o regime autoritário defendia não era a soberania nacional, tampouco a existência da comunidade política, mas sim a permanência dos próprios governos militares.

\section{Considerações Finais}

Em 1964, um movimento civil-militar tomou o poder do Estado e colocou as Forças Armadas como o grupo de maior visibilidade no cenário político brasileiro. Desde então, foi constante a busca por legitimidade. Dentre os vários recursos de obtenção da tal legitimidade está a legalidade, ou seja, o discurso de que as ações políticas do Estado foram pautadas pela obediência à legislação nacional.

Acreditamos firmemente que o sucesso dos governos militares em manter os generais presidentes, a política econômica que adotaram e a repressão àqueles que identificaram como inimigos podem também ser explicados pelo apelo à legalidade do regime.

Adeptos, mesmo que por conveniência, da concepção jurídica que defendia a necessidade do poder soberano para a manutenção da ordem de um dado país, as Forças Armadas evocaram e difundiram a idéia de que o governo, desde que 
HISTÓRIA E CULTURAS POLÍTICAS: AS CONCEPÇÕES JURÍDICAS ...

necessário, situa-se fora da lei e, ao mesmo tempo, dentro dela, no sentido de que pode decidir manter ou não o arcabouço jurídico-legal em vigor. Em nome da ordem, esse elemento extrajurídico e político por excelência, a suspensão da lei é permitida na esfera da própria legalidade.

Dos preâmbulos dos Atos Institucionais e dos discursos dos generais presidentes, salta aos olhos a recorrência a algumas reflexões de Carl Schmitt e Hans Kelsen. Do primeiro, lançaram mão da justificativa de um governo forte e autoritário, da defesa de uma ditadura soberana, argumentos evocados na implantação do autoritarismo em 1964 e nos anos imediatamente posteriores; do segundo, serviram-se principalmente da ideia de que as leis devem ser cumpridas e julgadas, isolando-as, ao máximo, das influências morais e das concepções históricas de cada período, argumentação útil depois que já estavam editadas as bases da legislação de exceção, ou seja, quando as próprias normas permitiam a publicação de outras.

O governo revolucionário instituído em 1964, para editar o AI-1, pautou-se por duas idéias: em elementos selecionados da teoria do poder constituinte e na argumentação teórica da necessidade da "ditadura soberana" em momentos de crise, mesmo que não tenham, obviamente, usado a palavra "ditadura". Como bem lembrou Giorgio Agamben, é possível considerar, mesmo que nos afastando da democracia, a soberania como norma suprema do ordenamento jurídico (como defende Kelsen) ou como potência externa ao Direito (como preconizou Schmitt). Se lançarmos mão dos conceitos de Kelsen e de Schmitt, a exceção pode ser justificada e aplicada sem que se perca o elemento da legalidade.

Os governos militares utilizaram o Direito em seu benefício e, ao contrário do que pensam aqueles que os caracterizam como o domínio exclusivo do arbítrio, a legalidade foi essencial para a permanência dos mesmos por tantos anos. O Direito não foi simplesmente esquecido, mas evocado, por meio de teorias que bem serviam para sustentar o estado de exceção. Os governos militares, mesmo que não tenham logrado êxito na construção do simulacro de legalidade em todas as instâncias (a exemplo da 
MÁRCIA PEREIRA DA SILVA

aplicação da justiça), fizeram das leis instrumento privilegiado em defesa do arbítrio.

\section{Referências Bibliográficas}

AGAMBEN, G. Estado de Exceção. São Paulo: Bointempo, 2003. . Homo Sacer: o poder soberano e a vida nua. Belo Horizonte: UFMG, 2002.

AGUIAR, R. A. R. Os Militares e a Constituinte. Poder Civil e Poder Militar na Constituição. São Paulo: Alfa Omega, 1986.

ALMOND, G.; VERBA, S. The civic culture: political attitudes and democracy en five nations. Princeton: Princeton University press, 1989.

AMARAL, G. L. et al. Quantidade de normas editadas no Brasil: 20 anos da Constituição Federal de 1988. Instituto Brasileiro de Planejamento Tributário. Disponível em <www.ibpt.com.br>.

ARENDT, H. Origens do Totalitarismo. Anti-Semitismo, Imperialismo e Totalitarismo. São Paulo: Cia das Letras, 1989.

BOBBIO, N., MATTEUCCI, N., PASOUINO, G. Dicionário de política. Verbetes autoritarismo e legitimidade. v.1. 12 ed. Brasília: UnB, 1999, p.94-104, p.675-679.

BORGES, N. A Doutrina de Segurança Nacional e os governos militares. In: FERREIRA, J.; DELGADO, L. A. N. (orgs.). O tempo da ditadura: regime militar e movimentos sociais em fins do século XX. Rio de Janeiro: Civilização Brasileira, 2003, p.13-42. (Col. O Brasil Republicano, v.4).

CARDOSO, I. O arbítrio transformado em lei e a tortura política. In: FREIRE, A. et al. (orgs). Tiradentes, um presídio da ditadura. São Paulo: Scipione, 1997.

FERREIRA FILHO, Manoel Gonçalves. Aspectos do Direito Constitucional Contemporâneo. São Paulo: Saraiva, 2003.

HOBBES, T. Leviatã. São Paulo: Abril Cultural, 1974 (Coleção Os Pensadores).

HOBSBAWM, E. O novo século: entrevista a Antônio Polito. São Paulo: Cia das Letras, 2000.

KELSEN, H. Quem deve ser o guardião da Constituição?. In:

Jurisdição Constitucional. Tradução de Alexandre Krug. São Paulo: Martins Fontes, 2003, p. 237-298. 
HISTÓRIA E CULTURAS POLÍTICAS: AS CONCEPÇÕES JURÍDICAS ...

. O que é justiça: a justiça, o direito e a política no espelho da ciência. Tradução: Luís Carlos Borges. São Paulo: Martins Fontes, 3.ed. ,2001.

- Teoria pura do direito. 4ed. Coimbra: Armênio Amado, 1979.

LEMOS, R. Poder Judiciário e poder militar (1964-69). In: CASTRO, C.; IZECKSOHN, V.; KRAAY, H. Nova história militar brasileira. Rio de Janeiro: FGV, 2004.

LOCKE, J. Segundo tratado sobre os governos. São Paulo: Abril Cultural, 1973. (Coleção Os Pensadores)

LOEWENSTEIN, K. Teoria de la Constitución. Barcelona: Ariel, 1965.

O'DONNELL, G. Autoritarismo e democratização. São Paulo: Vértice, 1985.

REIS FILHO, D. A. A Ditadura Militar no Brasil: uma incômoda memória. Gramsci e o Brasil, 29 de março de 2001, p.1.

ROUQUIÉ, Alain. O Estado Militar na América Latina. São Paulo: AlfaÔmega, 1984.

ROUSSEAU, J. J.. A vontade geral é indiscutível. In: . O contrato social. Princípio de Direito Político. Livro $4^{\circ}$. Cap. 1. São Paulo: Ediouro Tecnoprint, s/d.

SCHMITT, C. O guardião da constituição. Tradução de Geraldo Luiz de Carvalho Neto, Belo Horizonte: Ed. Del Rey, 2007. .O Conceito de Político. Petrópolis: Vozes, 1992.

. La Dictadura. Madrid: Revista de Occidente, 1968.

- La defesa de La Constitución - Estudio acerca de las diversas espécies y possibilidade de savaguardia de la constitución. Barcelona: labor, 1931.

SILVA, M. P., COTRIM, C. C. O arbítrio e a violência: a prática da tortura no governo militar brasileiro. Unimontes Científica. Montes Claros: Unimontes, 2004, pp. 83-91.

SIEYÈS, E. J. Qu'est-ce que lê Tiers État? Paris: Éditions Flammarion, 1789/1988.

VIANNA FILHO, L. W. O governo Castelo Branco, v.1. Rio de Janeiro: Biblioteca do Exército: José Olimpio, 1975. 
MÁRCIA PEREIRA DA SILVA

SILVA, Márcia Pereira da. History and political cultures: the legal conceptions evoked by the military governments while score of getting legitimacy. História, v.28, n.2, p.17-42, 2009.

\begin{abstract}
This article proposes to analyse the period of brazilian military governments (1964-1985) under the view of lawfulness culture. We intend to show how the take of political power in 1964, far of being considered just the invest of the force and of the will, it was based into a juridical effort engagement, made upon a determined theory of constitutional right with emphasis in the thought of Carl Schmitt and Hans Kelsen.
\end{abstract}

Keywords: Political Culture; Armed Services; Brazil.

\title{
NOTAS
}

1 Utilizamos a denominação "governos militares" apenas para identificar o período, mas, convém salientar, não desconhecemos a participação de civis no aparelho burocrático, a base de apoio alcançada pelo Estado entre os diferentes setores sociais brasileiros, tampouco a diversidade dos grupos que compuseram a aliança civilmilitar responsável pela tomada do poder do Estado em 1964.

${ }^{2}$ Os termos "força" e "violência" não significam, necessariamente, a mesma coisa. Entendemos por "força" o emprego ou ameaça de agressão para obrigar pessoas a fazerem coisas que em outras circunstâncias não fariam. A "força" é permitida a grupos previamente estabelecidos da comunidade política para efeito de dominação ordenada e manutenção da própria sociedade. Para se configurar em "força", a agressão deve sempre obedecer ao motivo do bem geral de todos, no sentido de que ninguém pode fazer exatamente o que quiser, já que há leis e procedimentos comuns previamente acordados pela comunidade política. Diferentemente da "força", a "violência" extrapola o uso de agressões e coação física para além das razões de defesa e sobrevivência do Estado. Significa utilizar agressões e ameaças de qualquer tipo para fins relacionados muito mais com os objetivos daqueles que delas fazem uso. $\mathrm{O}$ emprego da violência não obedece a nenhuma lei e não tem como fim último a sobrevivência da 
HISTÓRIA E CULTURAS POLÍTICAS: AS CONCEPÇÕES JURÍDICAS ...

comunidade política. Partindo dos conceitos expostos, "força" e "violência" compreendem ações distintas, mas os governos militares no Brasil se valeram das duas. Para a primeira, os militares aumentaram, nos textos jurídicos que produziram, as ocasiões e motivos em que era permitido o uso da força. Já a violência foi traduzida, sobretudo, na tortura, artifício sistematicamente utilizado para desarticular a oposição e eliminar os inimigos do governo. A tortura se traduz pela "violência" e não pela "força", em virtude da mesma não servir para resguardar a sobrevivência da comunidade política ou da nação, e sim para permitir a permanência do governo. "Força" e "violência" estiveram, lado a lado, presentes na repressão. A força foi rotinizada no cumprimento de leis que nunca encontrariam eco num regime democrático e a violência foi amplamente exercida por ocasião dos inquéritos policiais que buscavam eliminar os inoportunos agentes da crítica social (SILVA, COTRIM, 2004: 84).

${ }^{3}$ As Constituições, segundo a clássica abordagem de Karl Loewenstein (1965), ainda podem ser de três tipos: normativas, nominais e semânticas. As Constituições normativas definem-se pela eficácia jurídica, alcançada em virtude de o texto expressar as concepções políticas da sociedade que regulamenta. A Lei maior, nesses casos, trata das ambições futuras de governantes e governados e, em virtude de seus artigos terem base na realidade, ambos se submetem a ela. No outro extremo estão as Constituições semânticas, um texto que se esforça para formalizar o poder político existente, em nome dos interesses do grupo que comanda o Estado. Já a Constituição nominal situa-se entre a normativa e a semântica. Nela existe um claro abismo entre a norma e a realidade política, mas o texto guarda em si a esperança futura de concretização. Nesse caso, a Lei máxima não é editada com a finalidade de mudar o presente a qualquer preço; espera-se pelo futuro, seja do país grande potência, do país rico ou do país educado. Segundo a concepção descrita, no Brasil nunca houve uma Constituição normativa, podendo as Constituições republicanas de 1891, 1934, 1946 e 1988 pretenderem o status de nominais, as demais - 1937, 1967 e a Emenda n. 1 de 1969 seriam semânticas.

${ }^{4}$ Como já alertou Hannah Arendt (1989), nem na Alemanha nazista foi possível descartar de pronto a tradição democrática: nos primeiros anos do poder, os nazistas desencadearam uma avalanche de leis e decretos, culminando com a promulgação das Leis de Nuremberg (que institucionalizaram as perseguições aos judeus). Posteriormente, ficou 
MÁRCIA PEREIRA DA SILVA

evidente que a legalidade não teria muita importância na construção do Estado totalitário.

${ }^{5}$ Guilherme O'Donnel, ao comparar o Brasil com os Estados autoritários da América Latina, considerou que os governos brasileiros talvez fossem mais burocratizados e previsíveis exatamente pela grande preocupação em editar legislação que lhes dessem sustentação. Acerca de sua experiência na Argentina escreveu O'Donnel que aquele "regime em consonância com sua natureza profundamente terrorista recusava a estabelecer quaisquer regras claras sobre o que era ou não passível de punição, era praticamente impossível sentir-se seguro. Em nossos melancólicos encontros com amigos (de outros países da América Latina) acabávamos descobrindo que sentíamos inveja de seus regimes não menos repressivos, porém mais burocratizados e, portanto, mais previsíveis". O'DONNEL (1985:104).

${ }^{6}$ Idéias semelhantes podem ser encontradas nos conhecidos teóricos do "contrato social". Ver: ROUSSEAU, s/d; LOCKE, 1973; HOBBES, 1974.

${ }^{7}$ Apesar do anti-semitismo e de ter justificado assassinatos cometidos em nome da raça pura, Schimitt teve uma vida extremamente contraditória, chegando a ser acusado de oportunista pela polícia nazista.

${ }^{8}$ BP. SILVA, Arthur da Costa e. Discurso de Apresentação do AI-1. Rio de Janeiro, 09 de abril de 1964. É importante enfatizar que a autoria do texto é atribuída a Francisco Campos.

Artigo recebido em 02/2009. Aprovado em 06/2009. 